\title{
KEBERADAAN PAJAK BUMI DAN BANGUNAN SEBAGAI PAJAK PUSAT DALAM ERA OTONOMI DAERAH
}

\author{
Hernanda Bagus Priandana, SH.
}

Latar belakang tesis ini adalah kebijakan Pajak Bumi dan Bangunan belum sesuai dengan asas-asas sistem pengelolaan Keuangan Daerah seperti asas transparansi dan asas efisiensi. Penelitian ini meneliti tentang kemungkinan daerah meningkatkan penerimaan daerahnya dari PBB sebagai Pajak Daerah tetapi lebih menekankan kepada pelaksanaan dan kendala dalam penerapan Law Enforcement Pajak Bumi dan Bangunan.

Tujuan penyusunan tesis ini adalah untuk mengetahui kemungkinan pemerintah pusat dapat menyerahkan PBB kepada Pemerintah Daerah sebagai pajak daerah sebagai upaya untuk menaikkan penerimaan daerah dengan berlakunya UU Nomor 12 Tahun 2008 tentang Pemerintahan Daerah dan UU Nomor 33 Tahun 2004 tentang Perimbangan Keuangan Antara Pusat dan Daerah, dan untuk mengetahui administrasi pengelolaan PBB di mana Pemerintah Daerah dalam pelaksanaan pemungutannya ikut berperan aktif, sehingga apabila mampu memungkinkan Pemerintah Daerah dapat mengambil alih pengelolaan PBB seperti yang telah berjalan selama ini.

Penelitian ini merupakan penelitian yang bersifat yuridis empiris karena penelitian ini menitikberatkan pada penelitian lapangan secara menyeluruh, sistematis dan akurat, serta ditunjang dengan penelitian kepustakaan. Data yang terkumpul dianalisis secara deskriptif analistis.

Dari hasil penelitian ini dapat disimpulkan bahwa penarikan PBB sebagai pajak daerah oleh Pemerintah Daerah dengan berlakunya UU Nomor 12 Tahun 2008 tentang Pemerintahan Daerah dan UU No 33 Tahun 2004 tentang Perimbangan Keuangan Antara Pusat dan Daerah, sebagai upaya untuk mewujudkan desentralisasi fiskal sebenarnya dapat dilaksanakan tetapi dengan aturan yang jelas dan pelaksanaan yang tepat sehingga tidak merugikan masyarakat sebagai pelaku pembayar pajak 
Dan seharusnya dengan desentralisasi fiskal akan lebih banyak memberikan manfaat dengan lebih memperhatikan faktor keadilan yang sama bagi semua subjek pajak, dan subsidi selama ini masih tetap menjadi sumber utama keuangan daerah. Serta siapapun pengelola administrasi dari PBB baik dari Pemerintah Pusat maupun Pemerintah Daerah seharusnya didukung oleh faktor SDM, teknologi dan biaya.

Kata kunci : pajak bumi dan bangunan, pajak pusat, otonomi daerah

\section{PENDAHULUAN}

\section{A.1. Latar Belakang Masalah}

Pajak Bumi dan Bangunan (PBB)

merupakan pajak yang mulai berlaku pada tanggal 1 Januari 1986 berdasarkan UU No. 12 Tahun 1985. Kemudian UU ini diubah dengan UU No. 12 Tahun 1998 dan mulai berlaku terhitung 1 Januari 1995. Pajak Bumi dan Bangunan adalah penerimaan pajak pusat yang sebagian besar hasilnya diserahkan kepada Daerah, karena PBB termasuk jenis pajak yang penerimaannya dibagi-bagikan kepada daerah sebagai bagi hasil dana perimbangan (revenue sharing) dan dalam Anggaran Pendapatan dan Belanja Daerah (APBD), penerimaan PBB tersebut dimasukkan dalam kelompok penerimaan Bagi Hasil Pajak.

Imbangan pembagian penerimaan PBB diatur melalui PP Nomor 16 Tahun 2000 tanggal 10 Maret 2000 tentang Pembagian Hasil Penerimaan Pajak Bumi dan Bangunan antara Pemerintah Pusat dan Daerah, dan Keputusan Menteri Keuangan Republik Indonesia nomor 82/KMK.04/2000 tanggal 21 Maret 2000 tentang Pembagian Hasil Penerimaan Pajak Bumi dan Bangunan antara Pemerintah Pusat dan Daerah, serta pasal 18 UU Nomor 12 Tahun 1994 Tentang Pajak Bumi dan Bangunan, di mana berdasarkan peraturan tersebut, rincian bagian daerah dari penerimaan PBB adalah sebagai berikut :

1. Untuk Pemerintah Pusat sebesar 10\%, dikembalikan lagi kepada daerah dengan rincian :

a) $65 \%$ dibagikan secara merata kepada seluruh Daerah Kabupaten/Kota

b) $35 \%$ dibagikan sebagai insentif kepada Daerah Kabupaten/Kota yang realisasi penerimaan Pajak Bumi dan Bangunan sektor pedesaan dan perkotaan pada Tahun Anggaran sebelumnya mencapai/ melampaui rencana penerimaan yang ditetapkan.

2. Untuk Daerah sebesar $90 \%$, dengan rincian :

a) 16,2\% untuk Daerah Propinsi yang bersangkutan

b) $64,8 \%$ untuk Daerah Kabupaten/Kota yang bersangkutan 
c) $9 \%$ untuk Biaya Pemungutan, yang berdasarkan ketentuan yang berlaku juga dikembalikan sebagian kepada daerah kabupaten dan kota, atas peran serta mereka dalam ikut bekerjasama untuk mengamankan upaya pemungutan penerimaan $\mathrm{PBB}$.

Wacana desentralisasi fiskal kemudian muncul dengan mulai diberlakukannya kebijakan pemerintah tentang Otonomi Daerah, yang dilaksanakan secara efektif tanggal 1 Januari 2001. Kebijakan tersebut diwujudkan dalam 2 (dua) Undangundang, yaitu UU Nomor 22 tahun 1999 jo UU Nomor 32 Tahun 2004 jo UU Nomor 12 tahun 2008 tentang Pemerintahan Daerah dan UU Nomor 25 Tahun 1999 jo UU Nomor 33 tahun 2004 tentang Perimbangan Keuangan Antara Pemerintah Pusat dan Daerah.

Dari perkembangan antara pro dan kontra atas kedua UU tersebut, berkembang pemikiran untuk menjadikan PBB sebagai pajak daerah. Di Indonesia, salah satu kebijakan pajak dari pemerintah pusat yang mempunyai pengaruh cukup signifikan terhadap APBD yaitu PBB. Oleh karena itu dalam merumuskan kebijakan $\mathrm{PBB}$, pemerintah pusat dan pemerintah daerah senantiasa melakukannya dengan penuh kehatihatian karena PBB terkait dengan berbagai aspek lainnya yang sangat sensitif baik secara ekonomi maupun secara politik.
PBB jika dirancang baik-baik dapat menjadi sumber penerimaan yang besar, stabil dan elastis. Kadar elastisitas tergantung pada sampai seberapa jauh tanah bersangkutan dapat ditaksir dengan teratur dan dapat dinilai menurut harga pasar yang berlaku. PBB dapat juga memperkuat peranan pemerintah daerah, karena membuka peluang dasar pajak yang lebih luas bagi penerimaan pemerintah sendiri. PBB yang efektif akan menciptakan sumber penerimaan yang kuat bagi pemerintah daerah dan memperkecil kebutuhan akan bantuan dari pemerintah pusat. $^{45}$

\section{Walaupun kontribusi PBB} tidaklah terlalu besar dalam struktur penerimaan negara, tetapi sangat berarti dan tidak mungkin dihilangkan.Seperti diungkapkan oleh Santoso Brotodihardjo, bahwa betapapun kecilnya jumlah uang yang akan dapat masuk kedalam kas negara, uang itu selalu akan dapat dipergunakan sebagai sumbangan untuk menutupi biaya-biaya pemerintahannya. ${ }^{46}$

PBB termasuk jenis pajak yang sulit dalam pengadministrasiannya dan mempunyai efisiensi pemungutan yang rendah karena jumlah obyek pajaknya

${ }^{45}$ Kelly, Roy, 1989, Keuangan Pemerintah Daerah di Indonesia (Keuangan Pemerintah Daerah di Indonesia), UI Press, Jakarta. halaman : 120

46 Brotodihardjo, Santoso, 2003, Pengantar Ilmu Hukum Pajak, Edisi Keempat, Refika Aditama, Bandung. Halaman : 220 
yang cukup banyak. NJOP sebagai dasar pengenaan $\mathrm{PBB}$ juga menjadi dasar perhitungan $\mathrm{PPh}$ final atas penjualan properti, serta Bea Perolehan Hak Atas Tanah dan Bangunan (BPHTB) atas hak yang telah diterima oleh pembeli. Bahkan masyarakat dan institusi tertentu juga menggunakan NJOP sebagai dasar dalam penghitungan kegiatan kredit perbankan, gadai, tukar guling (ruislag), ganti rugi, penilaian aset swasta dan pemerintah, dan kegiatan lainnya.

Pada masa mendatang PBB tidak hanya memfokuskan pada peningkatan penerimaan tetapi mempunyai banyak fungsi lainnya (multipurpose). Pemanfaatan data PBB berbasis teknologi Informasi yang komprehensif yang terintregasi mulai dari SISMIOP (Sistim Informasi Manajemen Obyek Pajak) yang kemudian dikembangkan ke arah Bank Data Nasional melalui program SIG PBB (Sistim Informasi Geografis PBB) yaitu dengan mempetakan secara digital semua obyek pajak PBB dan kemudian melinkkan semua data PBB yang telah mencakup \pm 84 juta obyek pajak dan \pm 75 juta wajib pajak dalam program SIN (Single Identification Number), yaitu program pengisian peta tersebut dengan data dari subyek pajak yang berkaitan dengan semua nomor identitas dari subyek pajak seperti KTP, SIM, STNK, NPWP, tagihan air, listrik, dan telepon dan lain sebagainya bahkan sampai ke nomor rekening Bank dari subyek pajak, sehingga nantinya memungkinkan semua instansi yang terkait seperti Kantor Pelayanan Pajak, Badan Pertanahan Nasional, Perbankan, Dinas Kependudukan, Imigrasi, bahkan Kepolisian dapat menggunakan dan mengaksesnya melalui Bank Data SIN PBB.

Demikianlah bahwa eksistensi PBB tidak hanya penting sebagai sumber penerimaan daerah, tetapi juga strategis dan signifikan pengaruhnya terhadap berbagai aspek kegiatan dan kehidupan masyarakat. Seperti diketahui hampir semua kegiatan manusia berlangsung di atas bumi dan terkait dengan persoalan bumi dan bangunan. Oleh karena itu, segala sesuatu yang berkenaan dengannya sangat sensitif bagi masyarakat. Dan sampai saat ini pengelolaan PBB di Indonesia masih menggunakan sistem terpusat karena berbagai pertimbangan yang telah memenuhi tujuan pokok dari perpajakan nasional dan prinsip-prinsip dasar perpajakan internasional. Dan sampai sejauh ini pula bentuk pengelolaan adalah terpusat dalam pengertian bahwa peraturan perundangannya ditetapkan oleh Pemerintah Pusat, administrasi dikelola pada level nasional walaupun Pemerintah Daerah dalam beberapa hal terlibat.

\section{A.2. Permasalahan}

Mencermati upaya untuk menjadikan PBB sebagai pajak daerah, ada beberapa hal yang perlu dipertanyakan. Apakah upaya tersebut sudah obyektif dan sudah didukung dengan penelitian atau merupakan hasil pengkajian yang mendalam? Apakah upaya tersebut memang 
benar-benar merupakan tuntunan dari masyarakat sehingga mencerminkan kebijakan yang bottom up atau hanya pemikiran-pemikiran yang parsial dari sekelompok kepentingan?

Berdasarkan uraian yang dikemukakan di atas, maka permasalahan penelitian dapat dirumuskan sebagai berikut:

1. Apakah ada kemungkinan Pemerintah Pusat dapat menyerahkan PBB kepada Pemerintah Daerah sebagai pajak daerah untuk menaikkan penerimaan daerahnya dengan berlakunya UU No. 12 Tahun 2008 Tentang Pemerintahan Daerah dan UU No. 33 Tahun 2004 Tentang Perimbangan Keuangan antara Pusat dan Daerah?

2. Apakah Pemerintah Daerah mampu melaksanakan dan pengambilalihan administrasi pengelolaan PBB?

\section{A.3. Tujuan Penelitian}

1. Untuk mengetahui adanya kemungkinan Pemerintah Pusat menyerahkan PBB kepada Pemerintah Daerah sebagai pajak daerah untuk dapat menaikkan penerimaan daerahnya dengan beriakunya UU No. 12 Tahun 2008 Tentang Pemerintahan Daerah dan UU No. 33 Tahun 2004 Tentang Perimbangan Keuangan antara Pusat dan Daerah.

2. Untuk mengetahui administrasi pengelolaan PBB dimana Pemerintah Daerah dalam pelaksanaan pemungutannya ikut berperan aktif, sehingga apabila mampu memungkinkan Pemerintah Daerah dapat mengambil alih pengelolaan PBB seperti yang telah berjalan selama ini.

\section{A.4. Tinjauan Pustaka}

\section{Otonomi Daerah dan Desentralisasi}

Otonomi daerah di Indonesia telah dilaksanakan sejak 1 Januari 2001. Instrumen regulasi dalam mendukung penyelenggaraan otonomi daerah dituangkan dalam Undang-undang No. 22 Tahun 1999 sebagaimana diubah dengan Undang-undang No. 32 Tahun 2004 dan diubah UU No.12 tahun 2008 Tentang Pemerintahan Daerah dan Undang-undang Nomor 25 Tahun 1999 sebagaimana diubah dengan Undang-undang Nomor 33 Tahun 2004 Tentang Perimbangan Keuangan Antara Pusat dan Daerah.

Istilah otonomi mempunyai makna kebebasan atau kemandirian (zelftandigheid) tetapi bukan kemerdekaan (onafharzkelijkheid). Kebebasan yang terbatas atau kemandirian itu adalah wujud pemberian kesempatan yang harus dipertanggung-jawabkan. Kebebasan dan kemandirian itu adalah kebebasan dan kemandirian dalam ikatan kesatuan yang lebih besar. Otonomi sekadar subsistem dari sistem kesatuan yang lebih besar. Otonomi adalah fenomena negara kesatuan. Negara kesatuan merupakan 
landasan dari pengertian dan isi otonomi. $^{47}$

Untuk selanjutnya UU No. 22 Tahun 1999 direvisi menjadi UU No. 32 Tahun 2004 dan direvisi manjadi UU No.12 tahun 2008 . Sedangkan UU No. 25 Tahun 1999 tentang Perimbangan Keuangan Antara Pusat dan Daerah direvisi menjadi UU No. 33 Tahun 2004. Kedua UU ini merupakan langkah awal dalam memberikan nuansa baru dalam perkembangan otonomi daerah di Indonesia. Konsep otanomi daerah yang dikembangkan merupakan lompatan jauh ke depan dari konsep sentralisasi sebagaimana yang dianut dalam UU No.5 Tahun 1974 tentang Pemerintahan Daerah, dimana dalam UU ini kedudukan propinsi adalah sebagai daerah otonom dan sekaligus wilayah administrasi yang melaksanakan kewenangan pemerintah pusat yang didelegasikan kepada gubernur. Daerah Propinsi bukan merupakan pemerintah atasan dari daerah kabupaten dan daerah kota. Dengan demikian, daerah otonom propinsi dan daerah kabupaten dan daerah kota tidak melakukan hubungan hierarkhi.

Pemberian kedudukan propinsi sebagai daerah otonom dan sekaligus wilayah administrasi dilakukan dengan pertimbangan sebagaimana penjelasan UU No 22 Tahun 1999 tentang Pemerintahan

47 Juanda, 2004, Hukum Pemerintah Daerah, Pasang Surut Hubungan Kewenangan antara DPRD dan Kepala Daerah PT. Alumni Bandung. Halaman : 129
Daerah, bagian umum dasar pemikiran huruf g, yaitu :

1) Untuk memelihara hubungan yang serasi antara pusat dan daerah dalam kerangka Negara Kesatuan Republik Indonesia.

2) Untuk menyelenggarakan otonomi daerah yang bersifat lintas daerah kabupaten dan daerah kota serta melaksanakan kewenangan otonomi daerah yang belum dapat dilaksanakan oleh daerah kota.

3) Untuk melaksanakan tugas-tugas pemerintahan tertentu yang dilimpahkan dalam rangka pelaksanaan asas dekonsentrasi.

Meskipun UU No.22 Tahun 1999 sudah dianggap memberikan nuansa baru dalam sistem pemerintahan di Indonesia, namun dalam perkembangannya ternyata tidak sesuai dengan perkembangan keadaan, ketatanegaraan dan tuntutan penyelenggaraan otonomi daerah sehingga perlu diganti. Untuk itu pemerintah mengeluarkan UU No. 12 tahun 2008 tentang Pemerintahan Daerah. Hal ini disebutkan dalam dasar pertimbangan sebagaimana yang terdapat dalam konsideran UU No. 12 Tahun 2008 tentang Pemerintahan Daerah huruf c.

Demikian pula dengan UU No. 25 Tahun 1999 tentang Perimbangan Keuangan Antara Pusat dan Daerah. Undang-undang ini perlu diganti agar sesuai dengan perkembangan keadaan, kebutuhan dan aspirasi masyarakat dalam memperkokoh landasan pelaksanaan 
desentralisasi dan otonomi daerah di Negara Kesatuan RI. Untuk itulah pemerintah mengeluarkan UU No.33

Tahun 2004. Hal ini disebutkan dalam Dasar Pertimbangan sebagaimana yang terdapat dalam Konsideran UndangUndang No. 33 Tahun 2004 tentang pemerintah daerah huruf $d$.

Walaupun peluang untuk melaksanakan otonomi luas telah tercipta, namun ternyata terdapat berbagai kendala yang dihadapi daerah, antara lain aparat pemerintah daerah yang profesional belum cukup memadai, baik kuantitas maupun kualitasnya untuk menjalankan kewenangannya dan pertanggungjawaban atas segala urusan yang sudah diserahkan kepada daerah. Visi untuk memujudkan kesejahteraan masyarakat yang lebih baik melalui otonomi luas belum sama di antara semua pelaku pembangunan. Koordinasi antarinstansi di daerah masih kurang terselenggara sebagaimana yang diharapkan, apalagi menghadapi perkembangan global yang semakin tajam. Kelembagaan organisasi otonomi daerah belum tertata dengan baik akibat kurangnya pengalaman dan ketergantungan dari pusat yang amat besar.

\section{A.5. Metode Penelitian}

Metode penelitian yang digunakan dalam penelitian ini adalah metode penelitian yang bersifat yuridis empiris karena penelitian ini menitikberatkan pada penelitian lapangan secara menyeluruh, sistematis dan akurat, serta ditunjang dengan penelitian kepustakaan yang dimaksudkan untuk melengkapi data-data yang diperoleh melalui penelitian.

Hasil dari penelitian ini adalah deskriptif analistis. Bersifat deskriptif karena dari hasil penelitian ini diharapkan dapat memperoleh gambaran secara menyeluruh dan sistematis mengenai peraturan perundang-undangan tentang pemerintah daerah dan otonomi daerah yang berkaitan dengan peraturan perpajakan khususnya Pajak Bumi dan Bangunan dengan didasarkan pula kepada peraturan perundang-undangan tentang Perimbangan Keuangan antara Pusat dan daerah. Bersifat analistis karena kemudian dari hasil penelitian dilakukan suatu analisis terhadap pelaksanaan Pajak Bumi dan Bangunan yang selama ini berlaku di Indonesia untuk menjawab permasalahan yang berkaitan dengan otonomi daerah.

\section{HASIL PENELITIAN DAN PEMBAHASAN}

\section{B.1. Prospek Penyerahan PBB Oleh}

Pemerintah Pusat Kepada

Pemerintah Daerah Sebagai Pajak

Daerah Dengan Berlakunya

Undang-Undang Nomor 12 Tahun

2008 Dan Undang-Undang Nomor

33 Tahun 2004.

Hasil penelitian lapangan dan wawancara terhadap tesis ini dengan sampel 3 wilayah kabupaten yang berbeda 
berdasarkan kemampuan dan kemandirian daerah, masing-masing mempunyai pendapat dalam menyikapi tuntutan untuk menjadikan PBB menjadi pajak daerah, yaitu Untuk wilayah Kabupaten Sleman, walaupun tidak mendapat penerimaan dari sektor Perkebunan dan Perhutanan, tetapi daerah tersebut merasa mampu bila suatu saat PBB harus menjadi pajak daerah dengan konsekuensi tidak mendapat porsi bagi hasil dari dana perimbangan seperti yang selama ini diterima. Sedangkan untuk wilayah Temanggung maupun Sukoharjo, apabila PBB menjadi pajak daerah dan mereka tidak mendapat dana perimbangan dari sektor lain, maka dari sektor Pedesaan dan perkotaan saja tidak akan banyak berarti bagi penambahan penerimaan daerah mereka, sehingga lebih baik menurut mereka tetap mendapat dana perimbangan daripada tidak. Disitulah terlihat bahwa apabila PBB menjadi pajak daerah maka tentu saja daerah-daerah kaya dengan hasil perkebunan, perhutanan dan pertambangan akan merasa lebih senang daripada daerah-daerah miskin. Seharusnya kajian dari semua daerah di seluruh nusantara harus dapat mewakili kepentingan tersebut.

Selama ini kedudukan Pajak Bumi dan Bangunan (PBB) sebagai pajak pusat terdapat dalam penjelasan Pasal 3 ayat (2) UU No. 12 Tahun 1985 yang diubah dengan UU No. 12 Tahun 1994 Tentang Pajak Bumi dan Bangunan, yaitu :
"Pajak Bumi dan Bangunan adalah pajak negara yang sebagian besar penerimaannya merupakan pendapatan daerah yang antara lain dipergunakan untuk penyediaan fasilitas yang juga dinikmati oleh Pemerintah Pusat dan Pemerintah Daerah."

Kedudukan PBB sebagai pajak pusat atau pajak negara tersebut merupakan cerminan negara dalam melakukan fungsinya untuk melayani kebutuhan masyarakat. Dengan luasnya medan tanggung jawab negara, maka negara membutuhkan dukungan finansial dari rakyat. Untuk mengatur hal tersebut maka negara membuat ketentuan yang akan dijadikan pijakan untuk mengimbangi ketimpangan sosial dalam masyarakat dengan pajak. Hal ini ditetapkan dalam Pasal 23A UUD 1945 hasil amandemen, bahwa : "pajak dan pungutan lain yang bersifat memaksa untuk keperiuan negara diatur dengan undang-undang”. Akan tetapi negara juga mempunyai beban sosial kemanusiaan, dan untuk memenuhinya negara membuat ketentuan untuk mewajibkan warga negara atas dasar kedaulatan menanggung pembiayaan itu sesuai dengan kemampuan. Hal ini sesuai amanat dalam UUD 1945 Pasal 23 ayat (1), bahwa negara harus memberikan jaminan yang adil kepada rakyat dengan menggunakan uang pajak untuk sebesar-besarnya kemakmuran rakyat.

Kedudukan PBB dan BPHTB adalah sebagai salah satu sumber pen- 
dapatan daerah, dimana kedua pajak tersebut merupakan pajak pusat, sedangkan daerah hanya menerima bagian dari kedua pajak tersebut sebagai dana perimbangan. Hal ini dijelaskan dalam Pasal 160 ayat (2) huruf a UU No. 32 Tahun 2004 dan Pasal 11 ayat (2). Meskipun penerimaan $\mathrm{PBB}$ (termasuk BPHTB) memberikan kontribusi terhadap penerimaan perpajakan yang relatif kecil, namun PBB dan BPHTB merupakan sumber penerimaan yang sangat potensial bagi daerah. Sebagai salah satu jenis pajak langsung, PBB dan BPHTB merupakan pajak negara (pusat) yang seluruh hasil penerimaannya dibagikan kepada daerah dengan mekanisme tertentu.

Pada dasarnya pemungutan PBB dan BPHTB lebih diarahkan pada fungsi distributif, yaitu untuk menciptakan pemerataan, dengan tetap memperhatikan potensi daerah penghasil. Oleh karena itu semua kegiatan pemungutan dan upaya pengamanan penerimaan PBB dan BPHTB menjadi strategis bagi daerah karena terkait dan berdampak terhadap keberhasilan daerah dalam menjalankan kegiatan pelayanan masyarakat dan kegiatan pemerintahan lainnya di daerah.

Idealnya, sumber utama pembangunan daerah harus dapat dibiayai dari PAD, hingga daerah tidak tergantung dari subsidi pemerintah pusat. Akan tetapi, harapan tersebut bagi sebagian besar pemerintah daerah hanyalah sekedar mimpi belaka, bahwa tidak mungkin daerah dapat membangun hanya dengan bertumpu pada PAD saja. Oleh karena itu, daerah harus memperoleh subsidi dari pemerintah pusat yang kita kenal dengan "Dana Perimbangan", yang dimaksudkan untuk menanggulangi gap capacity dalam pembiayaan pembangunan daerah (APBD).

Pengklasifikasian pajak properti atau PBB sebagai pajak daerah atau pajak pusat harus dipahami tidak sesederhana menjiplak atau menduplikasi sistem yang berlaku di negara lain. Aspek tinjauan dalam pengelolaan pajak properti meliputi :

1. Aspek penerimaan (revenue).

Pajak properti merupakan sumber penerimaan yang potensial bagi daerah, maka dapat dijadikan sebagai pajak daerah

2. Aspek pengelolaan (administration). Aktivitas pengelolaan meliputi Identifikasi objek/subjek, Basis Data, Penilaian, dan Pemungutan. Dari aspek pengelolaannya, administrasi pajak properti sangat complicated dimana pajak properti dikenakan kepada semua objek properti sehingga harus tepat dalam pengklasifikasian tanah dan bangunannya dan membutuhkan biaya mahal dan tehnologi tinggi, maka sesuai bila menjadi pajak pusat

3. Aspek wewenang perumusan (policy). Untuk meningkatkan aspek local taxing power, akuntabilitas dan transparansi, lebih sesuai bila menjadi pajak daerah. 
Untuk kasus di Indonesia, pembagian kewenangan perpajakan tidak dapat diputuskan secara sepihak hanya oleh pemerintah pusat, akan tetapi diperlukan keterlibatan pemerintah daerah guna menghindari terjadinya kontra produktif kebijakan. Oleh karena itu, pemahaman terhadap konsep pajak oleh para elit birokrasi perpajakan baik di pusat maupun di daerah merupakan faktor penting dalam menentukan keberhasilan pembagian kewenangan. Para ekonom perpajakan memberikan kriteria terhadap penanganan pajak, yaitu pajak yang dikategorisasikan dan direkomendasikan untuk dikelola pusat adalah pajak yang secara sifat atau naturenya bermobilitas tinggi, sedangkan untuk pajak yang sifat atau naturenya tidak berubah direkomendasikan menjadi pajak daerah. Harus dipertimbangkan pula adanya disparitas fiskal yang berkaitan dengan kapasitas fiskal masing-masing daerah. Disparitas fiskal harus menjadi variabel kebijakan perpajakan, karena akan berkaitan dengan penentuan formulasi pola kewenangan, dan akan berpengaruh terhadap derajat desentralisasi kewenangan serta formulasi transfer dana sepanjang masih diperlukan. Dengan demikian, untuk mencapai tata pengelolaan kewenangan perpajakan yang baik, maka keterlihatan daerah dalam proses pembuatan kebijakan perpajakan tidak dapat diabaikan. ${ }^{48}$

48 (Edi Slamet-Syarifuddin, 2005:118)
Demikian pula, Arsyad ${ }^{49}$ berpendapat bahwa, sejalan dengan upaya memperkuat otonomi daerah, maka bantuan dari pemerintah pusat sesungguhnya merupakan instrumen yang diharapkan dapat memacu PAD dan bukan sebaliknya. Bahwa hakekat bantuan adalah untuk memperkuat tingkat otonomi suatu daerah, karena itu daerah perlu memiliki keleluasaan dalam menggunakan dana bantuan yang ada sehingga mempunyai dampak positif terhadap peningkatan PAD. Dengan perkataan lain keleluasaan dalam menggunakan bantuan tersebut menyebabkan daerah dapat memprioritaskan kegiatan-kegiatan yang dapat mendorong peningkatan PAD.

Dari berbagai studi yang telah dilakukan menyangkut deser.tralisasi fiskal, menunjukkan bahwa kabijakan desentralisasi fiskal masih belum dapat dipahami sebagai pelimpahan kewenangan kepada daerah dalam hal tugastugas pengeluaran dan pembagian penerimaan negara kepada daerah. Kekeliruan dalam cara memandang subtansi desentralisasi fiskal, melahirkan kebijakan fiskal yang bersifat reaktif dan tidak substantif karena hanya memenuhi aspek jangka pendek berupa transfer dana untuk menutup defisit APBD. Padahal kebijakan desentralisasi fiskal idealnya harus mengarah pada kemampuan peme-

49 Arsyad, Negara, 1990, Hubungan Fiskal antar pemerintah di Indonesia, Analisis, Tahun XIX, No. 3 halaman 23 
rintah daerah untuk menentukan pajak yang akan dikenakan, rancangan pajak dan akses langsung ke sumber pendanaan. $^{50}$

Perilaku pemerintah daerah dalam meningkatkan PAD melalui peningkatan pajak atau retribusi tidak terlepas dari kondisi sulitnya keuangan pemerintah daerah di masa otonomi daerah ini. Beberapa pemerintah daerah sebenarnya sangat menyadari penerapan pajak atau retribusi baru, dapat menimbulkan ekonomi biaya tinggi dan dapat menghambat kegiatan usahanya didaerah, sehingga perkembangan ekonomi setempat juga akan terhambat.

Pemerintah daerah yang wilayahnya tidak memiliki kekayaan alam tidak mempunyai kemampuan untuk menjaring pajak perusahaan, sebab $100 \%$ pajak perusahaan masih harus disetor kepada pemerintah pusat. Akibat kondisi tersebut maka pemerintah daerah dengan karakteristik perekonomian seperti itu kemudian mencari alternatif sumber PAD baru dengan menciptakan pajak-pajak baru yang bersifat distorsif. Sedangkan negara mempunyai keyakinan bahwa pembagian yang layak antara bagian pemerintah pusat clan pemerintah daerah diharapkan dapat mendorong terjadinya pertumbuhan pembangunan di daerah khususnya di bidang pertanahan. Daerah mendapat haknya dan pusat mendapatkan bagiannya.

50 (Edi Slamet-Syarifuddin, 2005:80).
Sedangkan M. Ryass Rasyid yang dikenal sebagai arsitek otonomi daerah, seperti yang dikutip dalam http://www. unisosdem.org/RyassRasyid: "Pemerintah Pusat Sumber Distorsi Otonomi Daerah", berpendapat bahwa pelaksanaan otonomi tak mungkin berjalan mulus tanpa bimbingan dan supervisi dari pemerintah pusat. Bimbingan dan supervisi harus diperkuat dengan peraturan yang cukup dalam bentuk keppres atau PP. Akibat tidak didukung peraturan lainnya, baik pemerintah pusat maupun pemerintah kabupaten/kota berjalan dengan pemahaman masing-masing. Bahkan, tidak sedikit kepala daerah dengan kewenangan yang dimilikinya tergiur kepentingan sesaat dengan menerbitkan izin-izin kehutanan atau pertambangan. Distorsi yang paling mencolok, antara lain soal retribusi dan perpajakan, kehutanan serta pertambangan dan kepegawaian di daerah. Distorsi bukan bersumber pada substansi undang-undangnya, tetapi pada pelaksana otonomi tersebut.

Beberapa pendapat diatas menjelaskan bahwa para pelaku otonomi daerah harus melihat undang-undang dan peraturan dalam pemahaman yang sama. Baik dari pemerintah pusat maupun pemerintah daerah. Apabila dikembalikan kepada wacana desentralisasi fiskal seperti pendaerahan $\mathrm{PBB}$, sebenarnya dapat dilaksanakan tetapi dengan aturan yang jelas dan pelaksanaan yang tepat sehingga tidak merugikan masyarakat sebagai pelaku pembayar pajak, dan seharusnya 
dengan desentralisasi fiskal akan lebih banyak memberikan manfaat dengan lebih memperhatikan faktor keadilan yang sama bagi semua subyek pajak.

Dari pendapat-pendapat diatas dan berdasarkan ketentuan-ketentuan yang diatur dalam UU No. 33 Tahun 2004 maka dapat disimpulkan :

1. Subsidi tetap menjadi sumber utama keuangan daerah (melalui dana perimbangan).

2. Sumber PAD tidak menjamin keleluasaan dan kemandirian daerah.
B.2. Kemampuan Pemerintah

\section{Daerah untuk melaksanakan} dan mengambil alih administrasi pengelolaan $\mathrm{Pbb}$.

Hasil penelitian lapangan yang dilakukan penulis terhadap para karyawan bidang pendapatan Kantor Dinas Pendapatan Daerah yang selama ini mengurusi administrasi pajak daerah dan juga membantu upaya pemungutan PBB di 3 (tiga) wilayah kabupaten yang berbeda, yaitu Kabupaten Temanggung, Kabupaten Sleman dan Kabupaten Sukoharjo ditunjukkan pada tabel dibawah ini.

Tabel 5 : Hasil penelitian Kemungkinan Pengalihan Administrasi PBB oleh Pemda

\section{A. Kab. Temanggung}

\begin{tabular}{|c|c|c|c|c|c|}
\hline \multirow{2}{*}{$\begin{array}{c}\text { Materi } \\
\text { Pengetahuan }\end{array}$} & Mengetahui & $\begin{array}{l}\text { Tidak mengetahui } \\
\text { sama sekali }\end{array}$ & $\begin{array}{l}\text { Mengetahui } \\
\text { tetapi tidak } \\
\text { Memahami }\end{array}$ & Mampu & $\begin{array}{l}\text { Tidak } \\
\text { Mampu }\end{array}$ \\
\cline { 2 - 5 } & & & & \\
\hline $\begin{array}{l}\text { 1. Cara Penghitungan PBB } \\
\text { Pendataan sampai terbentuk } \\
\text { SPPT PBB }\end{array}$ & $100 \%$ & $100 \%$ & & \\
\hline $\begin{array}{l}\text { 3. Mampu tidaknya Pemda } \\
\text { Mengambil alih adm PBB }\end{array}$ & & & & $60 \%$ & $40 \%$ \\
\hline $\begin{array}{l}\text { 4. Adanya Program SIG PBB } \\
\text { Dan SIN }\end{array}$ & $100 \%$ & & & \\
\hline
\end{tabular}

\section{B. Kab. Sleman}

\begin{tabular}{|c|l|l|l|l|l|}
\hline \multirow{2}{*}{$\begin{array}{c}\text { Materi } \\
\text { Pengetahuan }\end{array}$} & Mengetahui & $\begin{array}{l}\text { Tidak } \\
\text { mengetahui sama } \\
\text { sekali }\end{array}$ & $\begin{array}{l}\text { Mengetahui } \\
\text { tetapi tidak } \\
\text { Memahami }\end{array}$ & Mampu & $\begin{array}{l}\text { Tidak } \\
\text { Mampu }\end{array}$ \\
\cline { 2 - 5 } 1. Cara Penghitungan PBB & $100 \%$ & & & & \\
\hline
\end{tabular}




\begin{tabular}{|l|l|l|l|l|l|}
\hline $\begin{array}{c}\text { 2. Pola administrasi, mulai dari } \\
\text { Pendataan sampai terbentuk } \\
\text { SPPT PBB }\end{array}$ & $50 \%$ & $50 \%$ & & \\
\hline $\begin{array}{l}\text { 3. Mampu tidaknya Pemda } \\
\text { Mengambil alih adm PBB }\end{array}$ & $50 \%$ & $50 \%$ & $100 \%$ & & \\
\hline $\begin{array}{l}\text { 4. Adanya Program SIG PBB } \\
\text { Dan SIN }\end{array}$ & 5 & & & & \\
\hline
\end{tabular}

\section{Kab. Sukoharjo}

\begin{tabular}{|c|c|c|c|c|c|}
\hline \multirow{2}{*}{$\begin{array}{c}\text { Materi } \\
\text { Pengetahuan }\end{array}$} & Mengetahui & $\begin{array}{l}\text { Tidak mengetahui } \\
\text { sama sekali }\end{array}$ & $\begin{array}{l}\text { Mengetahui } \\
\text { tetapi tidak } \\
\text { Memahami }\end{array}$ & Mampu & $\begin{array}{l}\text { Tidak } \\
\text { Mampu }\end{array}$ \\
\cline { 2 - 5 } 1. Cara Penghitungan PBB & $80 \%$ & $20 \%$ & & & \\
\hline $\begin{array}{c}\text { 2. Pola administrasi, mulai dari } \\
\text { Pendataan sampai terbentuk } \\
\text { SPPT PBB Pemda }\end{array}$ & & & $100 \%$ & $20 \%$ \\
\hline $\begin{array}{l}\text { 3. Mampu tidaknya Pa } \\
\text { mengambil alih adm PBB }\end{array}$ & $10 \%$ & $90 \%$ & & & \\
\hline $\begin{array}{c}\text { 4.Adanya Program SIG PBB Dan } \\
\text { SIN }\end{array}$ & & & & \\
\hline
\end{tabular}

Materi pengetahuan dalam tabel tersebut merupakan pertanyaan pokok dalam kuisioner yang dibagikan kepada para responden, dimana dalam penelitian tersebut, faktor yang dianggap memberikan kontribusi mampu tidaknya Pemerintah Daerah (Pemda) mengambil alih administrasi PBB (seperti yang ditunjukkan tabel, pada materi pengetahuan nomor 4) antara lain adalah SDM yang ada balk kualitas maupun kuantitas, teknologi informasi yang memadai, pengetahuan tentang PBB yang cukup, dan keyakinan bahwa pemerintah daerah pasti mampu mengelola administrasi PBB. Tabel diatas memperlihatkan berbagai kemungkinan, akan tetapi terdapat kecenderungan bahwa pemerintah daerah merasa mampu untuk mengambil alih administrasi PBB dengan segala konsekuensi walaupun secara fakta kemampuan untuk mengenal tata cara administrasi PBB masih rendah meskipun pemerintah daerah sudah menjadi mitra kerja PBB sejak berubah dari IPEDA menjadi PBB. Keyakinan akan kemampuan SDM dari pemerintah daerah adalah bahwa dengan proses belajar 
kemungkinan menerima PBB sebagai pajak daerah akan dapat mereka jalankan pada semua administrasi mulai dari pendataan sampai dengan pemungutannya. Akan tetapi berbeda dengan para pengambil keputusan di Kantor Dinas Pendapatan Daerah yang lebih cenderung berpikir realistis bahwa untuk sementara PBB lebih baik sebagai pajak pusat daripada pajak daerah. Dengan berbagai pertimbangan tentunya, seperti SDM, faktor teknologi dan biaya.

Pada saat ini Undang-Undang Nomor 12 Tahun 1994 Tentang Pajak Bumi dan Bangunan PBB memberikan tanggung jawab menentukan nilai jual tanah pada pemerintah pusat. Meskipun wajib pajak diharuskan memberitahukan letak, nama wajib pajak, dan luas tanah dan bangunan dengan lengkap, jelas dan benar, tetapi adalah tugas pemerintah pusat dalam menaksir nilai jual tanah dan bangunan. Sektor-sektor khusus seperti perkebunan, kehutanan dan pertambangan, dinilai dengan cara tersendiri. Cara menetapkan nilai jual tersebut memungkinkan hitungan nilai jual yang lebih cermat dan karena itu, cara tersebut menciptakan sistem pajak tanah yang lebih adil dan efisien. Menurut UU PBB, penetapan nilai jual tanah diadakan tiga tahun sekali, kecuali ditempat-tempat yang cepat berkembang (misalkan di pinggir kota) penetapan diadakan setiap tahun.
Menurut Edi Slamet Syarifuddin ${ }^{51}$, administrasi perpajakan merupakan implementtasi kebijakan, sehingga pemerintah sebagai pengumpul pajak harus dapat melaksanakan administrasi perpajakan yang mudah diakses masyarakat pembayar pajak yang direpresentasikan dengan transparansi dan akuntabilitas.

Administrasi PBB yang paling rumit untuk dilaksanakan adalah pendataan subyek dan obyek pajak, karena PBB merupakan jenis pajak yang dikenakan terhadap seluruh lapisan masyarakat dengan harus memperhatikan aspek keadilan serta meminimalkan dampak terhadap distorsi ekonomi dan sosial. PBB termasuk jenis pajak yang sulit dalam pengadministrasiannya dan mempunyai efisiensi pemungutan yang rendah karena jumlah obyek pajaknya yang cukup banyak. Oleh karena itu, dalam pelaksanaannya disadari bahwa penyempurnaan sistem pemungutan merupakan prioritas dalam upaya meningkatkan penerimaan PBB. Untuk lebih memberikan kepastian hukum dan pelayanan kepada wajib pajak melalui ketersediaan basis data obyek dan subyek PBB yang memadai, mulai tahun 1999 dikembangkan suatu sistem yang memadukan dan menyelaraskan data alfanumeris dan data grafis obyek PBB

\footnotetext{
51 Irianto, Edi Slamet, - Syarifuddin Jurdi, 2005, Politik Perpajakan, Membangun Demokrasi Negara, UII Press, Yogyakarta. Halaman : 91
} 
yang dikenal dengan SIG PBB (Sistem Informasi Geografis PBB). Sistem ini terintegrasi dengan aplikasi SISMIOP (Sistem Informasi Manajemen Obyek Pajak) dan menekankan pada analisa spasial atau keruangan yang selama ini tidak tertampung dalam aplikasi SISMIOP.

Kemudian sejalan dengan perkembangan teknologi, pengadministrasian PBB tahun 2000 mulai memprioritaskan suatu program Bank Data Nasional yaitu SIN (Single Identification Number) untuk memadukan semua informasi dari subyek dan obyek PBB. Program SIN tersebut merupakan program pengisian peta SIG dengan data dari subyek pajak yang berkaitan dengan semua nomor identitas dari subyek pajak seperti KTP, SIM, STNK, NPWP, tagihan air, listrik, dan telepon dan lain sebagainya bahkan sampai ke nomor rekening Bank dari subyek pajak, sehingga nantinya memungkinkan semua instansi yang terkait seperti, Badan Pertanahan Nasional, Perbankan, Dinas Kependudukan, Imigrasi, bahkan $\mathrm{Ke}$ polisian dapat menggunakan dan mengaksesnya melalui Bank Data SIN PBB, dengan tujuan untuk memudahkan penggunaan data antar instansi, sehingga program ini menjadi program nasional melalui PBB.

Program-program yang dijalankan oleh Departemen Keuangan dalam hal ini adalah Direktorat Jenderal Pajak pada akhirnya bertujuan untuk meningkatkan profesionalisme di bidang pelayanan kepada semua subyek PBB. Sudah barang tentu semua upaya tersebut memerlukan biaya yang tidak sedikit karena penggunaan tehnologi tinggi. Seandainya administrasi yang sudah berjalan sekian lama tersebut diberikan kepada daerah dengan konsekuensi daerah yang mengadakan semua peralatan dan sumber daya manusianya, maka pertanyaan tentang desentralisasi fiskal seharusnya ditujukan langsung kesemua daerah baik daerah kaya maupun daerah miskin, sehingga jawaban atas kepentingan tersebut dapat terwakili secara obyektif.

\section{PENUTUP}

\section{C.1. KESIMPULAN}

a. Bahwa penyerahan PBB sebagai pajak daerah oleh Pemerintah Pusat kepada Pemerintah Daerah dengan berlakunya Undang-Undang Nomor 12 Tahun 2008 tentang Pemerintahan Daerah dan Undang-Undang Nomor 33 Tahun 2004 tentang Perimbangan Keuangan Antara Pusat dan Daerah, sebagai upaya untuk mewujudkan desentralisasi fiskal sebenarnya dapat dilaksanakan tetapi harus dilengkapi dengan adanya Undang-undang yang mengatur tentang pelimpahan tersebut sehingga ada kejelasan hukum sehingga tidak merugikan masyarakat sebagai pelaku pembayar pajak, dan seharusnya dengan desentralisasi fiskal akan lebih banyak memberikan 
manfaat dengan lebih memperhatikan faktor keadilan yang sama bagi semua subyek pajak. Dan bahwa subsidi selama ini masih tetap menjadi sumber utama keuangan daerah (melalui dana perimbangan) dan sumber PAD tidak menjamin keleluasaan dan kemandirian daerah, sehingga daerah harus berupaya untuk dapat menggali potensi daerah dalam peningkatan PADnya tanpa harus mengorbankan rakyat.

b. Kemungkinan Pemerintah Daerah akan melaksanakan dan mengambil alih administrasi pengelolaan PBB seperti yang telah berjalan selama ini, berdasarkan penelitian terdapat kecenderungan bahwa pemerintah daerah merasa mampu untuk mengambil alih administrasi PBB dengan segala konsekuensi walaupun secara fakta kemampuan untuk mengenal tata cara administrasi PBB masih rendah walaupun pemerintah daerah sudah menjadi mitra kerja PBB sejak lama. Akan tetapi berbeda dengan para pengambil keputusan di Kantor Dinas Pendapatan Daerah yang lebih cenderung berpikir realistis bahwa untuk sementara PBB lebih baik sebagai pajak pusat dari pada pajak daerah. Dengan berbagai pertimbangan tentunya, seperti SDM, faktor teknologi dan biaya.

\section{C.2. SARAN}

a. Desentralisasi fiskal dengan pendaerahan PBB bukan solusi yang tepat untuk sebuah kewenangan otonomi daerah yang luas apabila tidak diadakan penelitian, tindakan dan evaluasi khusus terhadap berbagai daerah. Penelitian dan kajian diperlukan sebagai upaya untuk menindaklanjuti berbagai peraturan perundangan yang dikeluarkan menyangkut terlaksananya otonomi daerah dan desentralisasi fiskal, sehingga diharapkan pelaksanaan otonomi daerah baik menyangkut kelembagaan, kewenangan dan tanggung jawab aparatur maupun sumber-sumber pembiayaan dan sarana serta prasarana pendukung lainnya benar-benar dipastikan telah ideal dan sesuai dengan aspirasi, tuntutan dan kebutuhan daerah otonom, sehingga tidak akan menimbulkan masalahmasalah fundamental di masa yang akan datang.

b. Pengalihan administrasi PBB yang sudah jelas, menggunakan tehnologi tinggi dan telah lama dilaksanakan harus diikuti dengan peningkatan kualitas sumber daya manusia melalui pelaksanaan seleksi yang jelas, ketat dan baik karena penyeleksian merupakan salah satu unsur dalam memantapkan pengembangan kualitas aparatur dan organisasional dari pemerintah 
daerah sendiri, yaitu dengan melalui pendidikan dan latihan, penempatan SDM melalui proses mekanisme yang baku dan obyektif serta professional sehingga akan memberikan sumbangsih bagi kemantapan terciptanya manajemen kepegawaian yang rasional dan modern hingga akan mendukung kinerja manajemen pemerintahan secara keseluruhan. Siapapun yang akan mengelola dan menjalankan administrasi PBB seharusnya adalah yang benar-benar mengetahui tentang tata cara pengadministrasian PBB mulai dari penetapan obyek dan subyek
PBB, pendataan, penghitungan sampai kepada pemungutannya, dan memahami betul semua aplikasi PBB dari mulai SISMIOP, SIG dan juga SIN, karena semua berbasis tehnologi yang pada akhirnya bertujuan untuk peningkatan kualitas pelayanan kepada masyarakat pembayar pajak dan meningkatkan penerimaan negara. Untuk itu daerah yang akan menerima tugas dan wewenang melaksanakannya harus benar-benar siap baik dari semua sumber daya yang ada, yaitu SDM, tehnologi dan finansialnya.

\section{DAFTAR PUSTAKA}

\section{BUKU}

Brotodihardjo, Santoso, 2003, Pengantar Ilmu Hukum Pajak, Edisi Keempat, Refika Aditama, Bandung

Irianto, Edi Slamet, Syarifuddin Jurdi, 2005, Politik Perpajakan, Membangun Demokrasi Negara, UII Press, Yogyakarta

Kelly, Roy, 1989, Keuangan Pemerintah Daerah di Indonesia (Keuangan Pemerintah Daerah di Indonesia), UI Press, Jakarta

\section{MAKALAH - ARTIKEL - JURNAL}

Arsyad, Negara, 1990, Hubungan Fiskal antar pemerintah di Indonesia, Analisis, Tahun XIX, No. 3
Rasyid, Ryass, "Pemerintah Pusat Sumber Distorsi Otonomi Daerah", http://www.unisosdem.org/Ryass $\underline{\text { Rasyid }}$

Sidik, Machfud, 2004, Prospek dan Problematika Pelaksanaan UU No. 25/1999 Tentang 
Perimbangan Keuangan Pusat- Undang-Undang Nomor 22 Tahun 1999 jo Daerah, Jurnal Hukum Bisnis, Undang-Undang Nomor 32 Tahun Vol. 23 No. 1 Tahun 2004, YPHB 2004 jo Undang-Undang Nomor Yayasan Pengembangan Hukum 12 Tahun 2008 Tentang Bisnis Pemerintahan Daerah;

PERATURAN PERUNDANG- Undang-Undang Nomor 25 Tahun 1999 jo UNDANGAN

Undang-Undang Dasar 1945 beserta
amandemennya

Undang-Undang Nomor 12 Tahun 1985 jo Undang-Undang Nomor 12 Tahun 1994 Tentang Pajak Bumi dan Bangunan;
Undang-Undang Nomor 33 Tahun 2004 Tentang Perimbangan Keuangan antara Pusat dan Daerah.

UU Nomor 18 Tahun 1997 jo UU Nomor 34 Tahun 2000 Tentang Pajak Daerah dan Retribusi Daerah 